\title{
The Effect of Aerobic and Anaerobic Interval Exercise on the Proliferation Phase of Wound Healing in Tooth Extraction of Rattus novergicus
}

\author{
Aqsa Sjuhada Oki, Nurul Farhana and Yuliati \\ Department of Oral Biology, Faculty of Dental Medicine, Universitas Airlangga, Surabaya, Indonesia
}

\begin{abstract}
Introduction. The healing process of tooth extraction is desired to take place faster to restore the normal tissue. Physical exercise is proven to accelerate wound healing through various physiological mechanisms. Aerobic exercise increases oxygen perfusion which leads to wound healing process. On the other hand, anaerobic exercise stimulates reactive oxygen species and may interfere with the wound healing process.
\end{abstract}

Objective. To observe if there are differences in the effectiveness of wound healing after tooth extraction based on the number of fibroblast and neovascularization in Wistar rats (Rattus norvegicus) that performed interval aerobic or anaerobic exercise.

Methods. Rats were divided into 3 groups, a control group and two treatment groups which performed the aerobic physical exercise or the anaerobic physical exercise. Fibroblast and neovascularization were calculated 7 days after the tooth extraction. Data were analyzed using Krusskal-Wallis statistical tests.

Results. The aerobic exercise group showed the higher number of fibroblasts and neovascularization compared to anaerobic exercise group, while the control group showed the lowest number of fibroblast and neovascularization.

Conclusion. This study demonstrated that aerobic physical exercise accelerates wound healing in the proliferation phase better than anaerobic exercise and no exercise.

Key Words: aerobic, anaerobic, physical exercise, wound healing, fibroblast, neovascularization, tooth extraction

\section{INTRODUCTION}

Paper presented at the Joint Scientific Meeting in Special Care Dentistry, July 5, 2019, Amerta Room, 4th Floor, main campus of Universitas Airlangga, Surabaya, Indonesia.

Corresponding author: Aqsa Sjuhada Oki

Department of Oral Biology

Faculty of Dental Medicine

Universitas Airlangga

J. Mayjen. Prof. Dr. Moestopo No. 47 Surabaya 60132 - Indonesia

Email: aqsa@fkg.unair.ac.id
Tooth extraction is an irreversible surgical procedure that is performed to remove teeth from the alveolar bone socket. These actions sometimes cause complications and are usually done using pliers, elevators, or the trans-alveolar approach. ${ }^{1}$ Tooth extraction will cause injury to the tooth socket. Wounds are the phenomenon that can heal on its own with a certain time depending on whether there is or no concurrent complications. If there are complications that accompany acute wounds, the healing phase will not occur in a timely manner and this can turn into a chronic wound which is more difficult to treat. ${ }^{2}$ Complications due to tooth extraction can occur due to various factors and complications that are often found in the tooth extraction including bleeding, swelling, pain, dry socket, fracture, and mandibular dislocation. ${ }^{3}$

Wound healing involves several cellular components, extracellular matrix, and cytokines. The wound healing process is divided into four phases, namely the coagulation phase and hemostasis, inflammatory phase, proliferation phase, and 
remodeling phase with scar tissue formation. ${ }^{2}$ In the third phase of wound healing which is the proliferation phase, there are other process known as fibroplasia and angiogenesis that play a major role in wound healing. Whether fibroplasia or angiogenesis, each process is very important in forming extracellular matrix and granulation tissue. ${ }^{4}$

Regular physical exercise produces positive effects on health such as reducing various cardiovascular diseases, metabolic syndrome disorders, and osteoporosis. Physical exercise is a series of physical activities that are structured and rhythmic with certain intensity over a period of time which results in increased use of energy or calories by the human body. ${ }^{5}$ Physical exercise can be classified into aerobic and anaerobic physical exercise. The types of exercise differ based on the intensity, interval, and the type of muscle fibers involved. Aerobic exercise involves large muscle groups, with mild to moderate intensity, and can be carried out continuously for quite a long time, while anaerobic physical exercise is a highintensity exercise and requires more energy in a short time. ${ }^{6}$

Previous studies have shown that physical exercise has been proven to heal wounds significantly when compared to those who do not exercise. ${ }^{7}$ Exercise physiologists also have discovered the ability of physical exercise in accelerating wound healing in mice and humans. ${ }^{8}$ Furthermore, continuous physical exercise with moderate intensity showed an increase in the number of fibroblasts and the amount of neovascularization in Wistar rats (Rattus norvegicus) after tooth extraction which results in acceleration of wound healing. ${ }^{9}$ In addition, there are also studies that have proven that there is an increase in vascular endothelial growth factors (VEGF) which triggers an increase in tissue neovascularization in the wound healing process after tooth extraction in Wistar rats (Rattus norvegicus) that perform moderate intensity physical exercise. ${ }^{10}$ From the background above, we determined if aerobic physical exercise accelerates the healing process in the proliferation phase compared to anaerobic physical exercise, based on the number of fibroblast and neovascularization in Wistar rats (Rattus norvegicus).

\section{MATERIAL AND METHODS}

This study was cleared by the faculty's Health Research Ethical Clearance Commission (Number 069/HRECC. FODM/VI/2018). This is an animal-based experimental study that used a quantitative approach with a research design that uses post-test only control group design. The experimental animals used as samples in this study were male Wistar rats (Rattus novergicus) which were around 12 weeks old and weighed around 200-250 grams.

The number of samples used for each group was 7 rats; $\mathrm{K}$ group (Control group that did not perform any of the exercise), P1 Group (group that performed aerobic physical exercise), and P2 Group (group that performed anaerobic physical exercise). The number of fibroblasts and neovascularization were examined on the 7 th day after tooth extraction.
The rats in the aerobic physical exercise group performed swimming in a clean bucket for 8 weeks with 3\% load of rat body weight (in the form of paper clips tied with a piece of thread placed on $1 / 3$ of the origin of the rat's tail). In this exercise, 8 minutes 8 seconds was taken as the training load which is $50 \%$ of the average time of the maximum swimming capacity (16 minutes 15 seconds). The training was followed by rest with a time period of $1 / 2$ of the training load time. This training program has a working time of 32 minutes 32 seconds, number of sets of 3 , with the duration of each set at 8 minutes 8 seconds, rest time $1 / 2$ of training load time which is equal to 4 minutes 4 seconds, and frequency of exercise of 3 times a week for a total of 8 weeks. By the 64th day, the mandibular left incisor was extracted.

The rats in the anaerobic exercise group performed intermittent swimming of 1 minute or $80 \%$ of the maximum swimming capacity (75 seconds). Training was then followed by rest with duration of $3 \mathrm{x}$ of the training load time. The additional load applied was $9 \%$ of rat body weight. The additional load applied was in the form of paper clips tied with a thread placed on $1 / 3$ of the origin of the rat's tail. This training program had a working time of 13 minutes, number of sets of 4 , with duration of each set as 1 minute, rest time of 3 times of the work time which was equal to 3 minutes, and frequency of exercise of 3 times a week for 8 weeks. By the 64th day, the mandibular left incisor was extracted.

On day 71 , the rats were sacrificed with ketamine and the mandible was taken. The mucosal tissue around the wound was taken for the histology examination after staining with Hematoxylin-Eosin (HE) stain (Merck Chemical, Germany). Histology examination and calculation of the number of fibroblasts and neovascularization were performed using a light microscope with 400 times magnification at 5 times field of view. The data obtained were analyzed using the ShapiroWilk test, the Krusskal-Wallis test and the Post-hoc test.

\section{RESULTS}

\section{Fibroblast Number}

Observation of fibroblast cells using $\mathrm{HE}$ staining can be seen in Figure 1. As shown in Table 1, the highest average number of fibroblasts was observed in $\mathrm{P} 1$ group (the aerobic interval exercise group) (24.74 \pm 2.50$)$, followed by $\mathrm{P} 2$ group (the anaerobic interval exercise group) (17.94 \pm 1.08$)$. The control group (K group) showed the lowest average in fibroblast number $(9.88 \pm 0.53)$; this showed that the number of fibroblasts increased with the exercises. The results of the Kruskal Wallis Test showed a significance level of 0,000 $(p<0.05)$ which reflected significant differences in the number of fibroblasts in the control group, aerobic interval exercise group, and anaerobic interval exercise group. Test to find differences between groups that performed exercises were then carried out to find if there was any significant difference between the groups. 

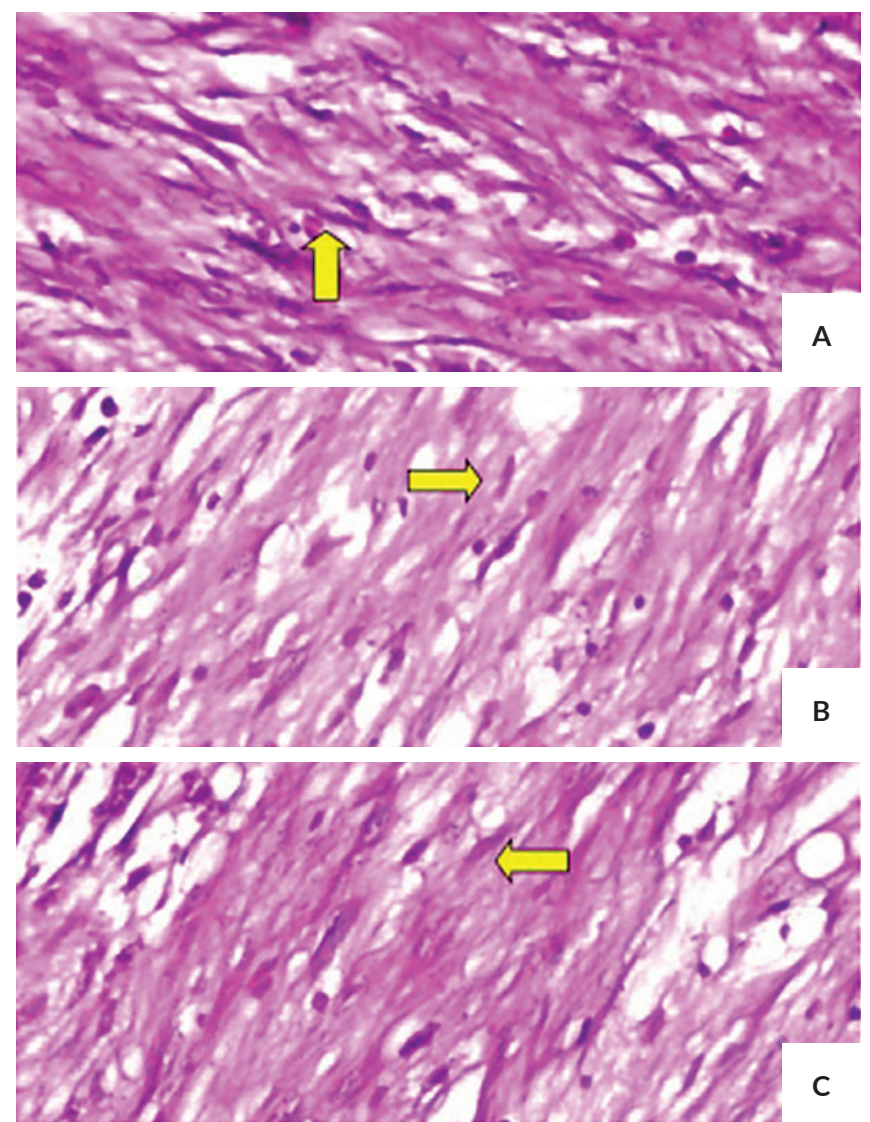

Figure 1. Description of fibroblast cells on the former socket extraction of the lower jaw incisor of Wistar rats with HE staining and microscope enlargement of 400x in the (A) control, (B) P1, and (C) P2 group.

The results of the Bonferroni Post Hoc Test showed a significant difference $(p<0.05)$ (Table 2$)$. There was significant difference in the number of fibroblasts post-dental extraction in Wistar rats that performed aerobic and anaerobic interval exercises.

Table 1. Average number and Standard Deviation of fibroblasts

\begin{tabular}{lcc} 
Sample group & $\begin{array}{c}\text { Average } \\
\text { Number }\end{array}$ & $\begin{array}{c}\text { Standard } \\
\text { Deviation }( \pm)\end{array}$ \\
\hline Control (K) & 9.88 & 0.53 \\
Aerobic interval exercise (P1) & 24.74 & 2.50 \\
Anaerobic interval exercise (P2) & 17.94 & 1.08 \\
\hline
\end{tabular}

Table 2. Difference test of fibroblast number between groups using Bonferroni Post Hoc Test

$\begin{array}{cccc} & & \text { Aerobic } & \text { Anaerobic } \\ \text { Groups } & \begin{array}{c}\text { Control } \\ \text { interval } \\ \text { (K) }\end{array} & \begin{array}{c}\text { exercise } \\ \text { (P1) }\end{array} & \begin{array}{c}\text { exercise } \\ \text { (P2) }\end{array}\end{array}$

Control (K)

Aerobic interval exercise (P1) $\quad<0.000^{*}$

Anaerobic interval exercise (P2) $\quad<0.000^{*}<0.000^{*}$

* Significant differences ( $p$-value $<0.05$ )
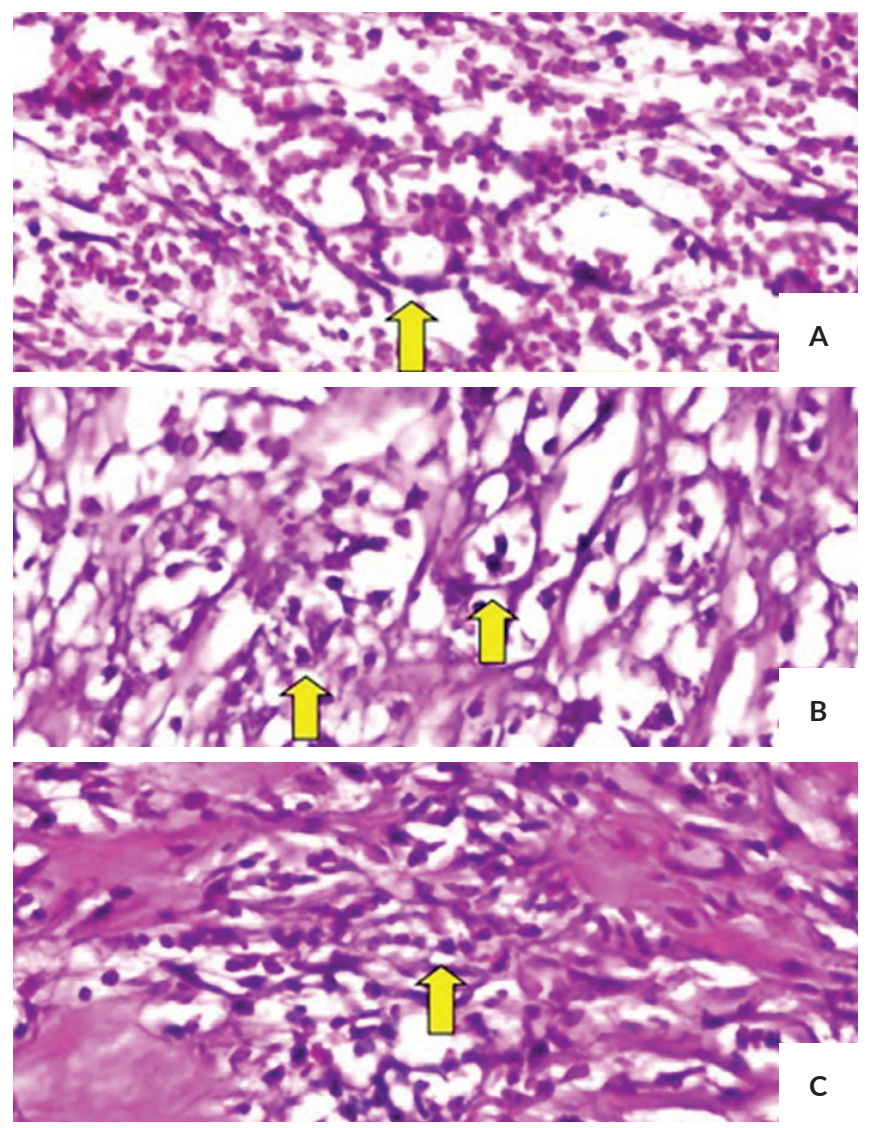

Figure 2. Description of neovascularisation on the former socket extraction of the lower jaw incisor of Wistar rats with $\mathrm{HE}$ staining and microscope enlargement of $400 x$ in the (A) control, (B) P1, and (C) P2 group.

\section{Neovascularization Number}

Observation of neovascularization cells using $\mathrm{HE}$ staining can be seen in Figure 2. As shown in Table 3, the highest average neovascularization number was seen in P1 group (the aerobic interval exercise group) (62.34 \pm 8.30$)$, followed by the P2 group (anaerobic interval exercise group) (37.80 \pm 3.56 ). The $K$ group (control) showed the lowest average neovascularization number $(21.63 \pm 1.62)$; this showed that the number of neovascularization increased with the given exercises.

The results of the Kruskal Wallis Test showed a significance level of $0,000(\mathrm{p}<0.05)$ which demonstrated significant differences in the number of neovascularization in the control group, aerobic interval exercise group, and anaerobic interval exercise group. Test to find differences between groups that performed exercises was then carried out to find which of the groups had significant differences.

The results of the Bonferroni Post Hoc Test showed a significant difference $(p<0.05)$ (Table 4). This showed that there were significant differences in the number of neovascularization post-dental extraction in Wistar rats that performed aerobic and anaerobic interval exercises. 
Table 3. Average number and Standard Deviation of neovascularization

\begin{tabular}{lcc} 
Sample group & $\begin{array}{c}\text { Average } \\
\text { Number }\end{array}$ & $\begin{array}{c}\text { Standard } \\
\text { Deviation }( \pm)\end{array}$ \\
\hline Control (K) & 21.63 & 1.62 \\
Aerobic interval exercise (P1) & 62.34 & 8.30 \\
Anaerobic interval exercise (P2) & 37.80 & 3.56 \\
\hline
\end{tabular}

Table 4. Difference test of neovascularization number between groups using Bonferroni Post Hoc Test

\begin{tabular}{lccc} 
Groups & $\begin{array}{c}\text { Control } \\
\text { (K) }\end{array}$ & $\begin{array}{c}\text { Aerobic } \\
\text { interval } \\
\text { exercise } \\
\text { (P1) }\end{array}$ & $\begin{array}{c}\text { Anaerobic } \\
\text { interval } \\
\text { exercise } \\
\text { (P2) }\end{array}$ \\
\hline Control (K) & \multicolumn{3}{l}{} \\
Aerobic interval exercise (P1) & $<0.000^{*}$ \\
Anaerobic interval exercise (P2) & $<0.000^{*}$ & $<0.000^{*}$ \\
\hline
\end{tabular}

* Significant differences $(p$-value $<0.05)$

\section{DISCUSSION}

In the proliferation phase of wound healing, there will be an increase in the number of cells and wound healing factors such as fibroblasts. The number of fibroblasts can be considered as a parameter of wound healing. ${ }^{11}$ In addition, the formation of new blood vessels can also be used as a parameter of the success of wound healing process. The more new blood vessels formed, the better supply of nutrients and oxygenation in the tissues, which then result in the avoidance of cell death. ${ }^{12}$ In this study, the aerobic interval exercise group had the most effective wound healing because it showed the highest number of fibroblasts and neovascularization.

Fibroblast is a primary tissue component that is very important for wound repair and recovery. These fibroblasts derived from mesenchymal cells play a role in producing most of the interstitial connective tissue extracellular matrix, making it the main element in the process of structural protein formation. Fibroblasts are very important in wound healing because of their functions that include synthesizing elastin, glycosaminoglycans, proteoglycans, multi adhesive glycoproteins, and collagen which are the key components in forming structural frames of tissues. ${ }^{13-14}$

Neovascularization is the key to the wound healing process. This is because of its role to supply oxygen and nutrition, and eliminate the necrotic tissue so that the wound healing process becomes more effective. New blood vessels are formed from pre-existing blood vessels. This process is called angiogenesis in which endothelial cells that line the inside of blood vessels are the target cells of the angiogenic regulator. Endothelial cells that are aroused will produce metalloproteinases which degrade the basement membrane and extracellular matrix (ECM), stimulate migration and proliferation of endothelial cells, secrete and differentiate collagen which results in the formation of shoots and eventually new blood vessel formation. ${ }^{12,15}$
In the initial phase of inflammation, wound sites often experience hypoxia. This is caused by vascularization disorders that have prevailed at the time of the onset of the wound, thus disrupting the process of oxygen delivery efficiently to the injured area. In addition to inflammatory cells that become active at that time, the process also requires a high source of oxygen so that the next wound healing phase can take place well. Aerobic physical exercise is able to give benefit on the cardiorespiratory fitness and increase oxygen uptake capacity which can be measured by $\mathrm{VO}_{2} \max$ values. With the increase in the value of $\mathrm{VO}_{2} \max$, the body will also be able to increase oxygen saturation and make the wound healing process to take place more effectively. ${ }^{16-17}$

This study showed that the wound healing process in rats that performed anaerobic physical exercise is not as effective as the wound healing process in rats that performed aerobic physical exercise. This might possibly be caused by increased production in lactic acid which triggers the formation of free radicals in anaerobic physical exercise. This results in a decrease of $\mathrm{pH}$ which tends to cause acidosis and interfere with the work of antioxidant enzymes. ${ }^{18}$ As a result, it will lead to a phenomenon called oxidative stress. Oxidative stress will trigger the release of leukocytes and make the inflammatory phase lasts longer. Free radicals can also increase lipid peroxidation which further damages the cell membrane and affects the wound healing phase. ${ }^{19-20}$

Excessive production of free radicals causes oxidative stress which can lead to a detrimental effect on wound healing. Continuous increase in the expression of free radicals has been detected in vivo and has been associated with disturbed wound repair, especially in chronic wounds that do not heal in a timely manner. At the molecular level, in addition to transcription mediated by free radicals that can cause induction of matrix metalloprotease and the continued secretion of pro-inflammatory cytokines, excessive free radicals can also directly and indirectly (through activation of proteolysis) modify and/or decrease extracellular matrix proteins causing interference to fibroblasts and keratinocyte function. ${ }^{21}$

Increase in free radical production has a cytotoxic effect that will cause phospholipid membrane peroxidation and increase in malondialdehyde as a result of lipid peroxidation in cell membranes and tissue damage and cause endothelial cell dysfunction. When free radicals exceed detoxification capacity, oxidative damage to lipids, nucleic acids, and proteins can occur. If this damage cannot be repaired, the cell will die, in the form of apoptosis (programmed cell death) or necrosis, depending on the level of damage..$^{22-23}$

Endoplasmic reticulum (ER) stress has been reported as one of the pathways through which cells are damaged and die after exposure to free radicals. But the mechanism by which ER stress promotes apoptosis cell depends on the accumulation of abnormal protein structures that are usually repaired by ER chaperones to prevent cell death. The right 
balance between the levels of low versus high free radicals is very important in determining functional results: Low levels of free radicals are very important in stimulating effective wound healing, while excessive release of free radicals results in cellular damage and impaired wound healing. ${ }^{21,24}$

This study showed that there was a significant difference in the results between the rats that performed aerobic interval physical exercise (P1) with the group that performed anaerobic interval physical exercise (P2). This study also showed that there was an increase in post-extraction wound healing process in rats that performed physical exercise (P1 and P2) when compared to rats that did not perform any of the exercises $(\mathrm{K})$; this is in accordance with the previous studies that have proven that the process of healing postextraction wounds can be improved by doing physical exercise. When compared with previous studies conducted by Oki that applied moderate intensity continuous exercise, this study showed similar results. ${ }^{25}$ Our results were also similar with the study performed by Setyadewi who proved that moderate intensity exercise increases the PMN and macrophage number in oral tissue wound healing. ${ }^{26}$ These findings succeeded in strengthening the theory that physical exercise can accelerate healing of wounds in the oral cavity.

\section{CONCLUSION}

Based on the results of this study, it can be concluded that there are differences in the number of fibroblasts and the number of neovascularization after tooth extraction in Wistar rats that performed aerobic or anaerobic interval exercise. This shows that aerobic physical exercise accelerates the healing process in the proliferation phase compared to anaerobic physical exercise.

\section{Acknowledgment}

Gratitude and appreciation are given to the Biochemistry Laboratory Staff member of the Faculty of Medicine Airlangga University for assistance with the process of experimental animals preparation.

\section{Statement of Authorship}

All authors participated in data collection and analysis, and approved the final version submitted.

\section{Author Disclosure}

All authors declared no conflict of interest.

\section{Funding Source}

None.

\section{REFERENCES}

1. Fakhrurrazi, Hakim RF, Ulfa L. The differences blood glucose levels at random before and after tooth extraction of the patients at dental installation RSUDZA Banda Aceh. Cakradonya Dent J. 2017; 9(2): 96-100.
2. Velnar T, Bailey T, Smrkolj V.The wound healing process: An overview of the cellular and molecular mechanisms. J Int Med Res. 2009 SepOct; 37(5): 1528-42.

3. Lande R, Kepel BJ, Siagian K V. Gambaran faktor risiko dan komplikasi pencabutan gigi di Rsgm Pspdg-Fk Unsrat. J e-GiGi. 2015; 3(2):476-81.

4. Greaves NS,Ashcroft KJ, Baguneid M,Bayat A. Current understanding of molecular and cellular mechanisms in fibroplasia and angiogenesis during acute wound healing. J Dermatol Sci. 2013 Dec; 72(3):206-17.

5. Harun L. Perbandingan kadar interleukin-6 dan jumlah limfosit setelah latihan aerobik ringan dan sedang pada remaja. Healthy MU Journal. 2018; 1(2):64-8.

6. Patel H, Alkhawam H, Madanieh R, Shah N, Kosmas CE, Vittorio TJ. Aerobic vs anaerobic exercise training effects on the cardiovascular system. World J Cardiol. 2017 Feb; 9(2):134-8.

7. Pence BD, Woods JA. Exercise, obesity, and cutaneous wound healing: Evidence from rodent and human studies. Adv Wound Care. 2014 Jan; 3(1):71-9.

8. Goh J, Ladiges WC. Exercise enhances wound healing and prevents cancer progression during aging by targeting macrophage polarity. Mech Ageing Dev. 2014 Jul; 139(1):41-8.

9. Egiarta BM. Peningkatan jumlah fibroblas dan neovaskularisasi pasca pencabutan gigi pada tikus wistar (Rattus norvegicus) yang diberi latihan kontinyu intensitas sedang. Universitas Airlangga, Surabaya; 2017.

10. Giffari FZ. Pengaruh latihan fisik intensitas sedang terhadap ekspresi vascular endothelial growth factors (VEGF) pada proses penyembuhan luka pencabutan gigi tikus wistar (Rattus norvegicus). Universitas Airlangga, Surabaya; 2016.

11. Putri RR, Hakim RF, Rezeki S. Pengaruh Ekstrak Daun Tapak Dara (Catharanthus Roseus) Terhadap Jumlah Fibroblas Pada Proses Penyembuhan Luka Di Mukosa Oral. Journal Caninus Dentistry. 2017; 2(1):20-30.

12. Nofikasari I, Rufaida A, Aqmarina CD, Failasofia, Fauzia AR, Handajani J. Efek aplikasi topikal gel ekstrak pandan wangi terhadap penyembuhan luka gingiva. Majalah Kedokteran Gigi Indonesia. 2016; 2(2):53-9.

13. Chiquet M, Katsaros C, Kletsas D. Multiple functions of gingival and mucoperiosteal fibroblasts in oral wound healing and repair. Periodontol 2000. 2015 Jun; 68(1): 21-40.

14. Hadian I, Alfianto U, Arianto AT. Ketotifen Mempengaruhi Jumlah Fibroblas dan Kepadatan Sel Kolagen Luka Insisi Tikus Wistar. Cermin Dunia Kedokteran. 2018; 45(2):90-3.

15. Nugroho AM, Elfiah U, Normasari R. Pengaruh Gel Ekstrak dan Serbuk Mentimun ( Cucumis sativus ) terhadap Angiogenesis pada Penyembuhan Luka Bakar Derajat IIB pada Tikus Wistar ( The Effect of Cucumber ( Cucumis sativus ) Gel Extract and Powder on Angiogenesis of the IIB Degree-Burn Wound Healing in Wistar Rat ). Pustaka Kesehatan. 2016; 4(3):443-8.

16. Handayani TU, Khotimah S. Perbedaan pengaruh latihan fisik aerobic dan land-based aerobic exercise terhadap peningkatan vo 2 max pada remaja. Naskah Publikasi. 2017.

17. Hong WX, Hu MS, Esquivel M, Liang GY, Rennert RC, Mcardle A, et al. The Role of Hypoxia-Inducible Factor in Wound Healing. Adv Wound Care. 2014 May; 3(5):390-9.

18. Arief H, Widodo MA. Peranan Stres Oksidatif Pada Proses Penyembuhan Luka Rules of Oxidative Stress in Wound Healing. Jurnal Ilmiah Kedokteran Wijaya Kusuma. 2018; 5(2):22-9.

19. Aryantie MW, Monica RD, Rezano A, Adi S, Rizki KA, Zuhairini Y. Plasma Malondialdehid and Histopatology Healing Score Differences in Incised Old and Young Mice with Zinc Administration. Journal of Medicine and Health. 2018; 2(1):655-71.

20. Harahap NS, Pahutar UP. Pengaruh aktifitas fisik aerobik dan anaerobik terhadap jumlah leukosit pada mahasiswa ilmu keolahragaan Universitas Negeri Medan. Jurnal Ilmiah Ilmu Keolahragaan. 2017; 1(2):33-41.

21. Dunnill C, Patton T, Brennan J, Barrett J, Dryden M, Cooke J, et al. Reactive oxygen species ( ROS ) and wound healing: the functional role of ROS and emerging ROS-modulating technologies 
for augmentation of the healing process. Int Wound J. 2017 Feb; 14(1):89-96.

22. Kupsco A, Schlenk D. Molecular mechanisms of selenium-Induced spinal deformities in fish. Aquat Toxicol. 2016 Oct; 179:143-50.

23. Irmawati A, Giffari FZ, Oki AS. The effect of moderate exercise on vascular endothelial growth factor expression during tooth socket wound healing after tooth extraction. J Postgrad Med Inst. 2018; 32(1):19-23.

24. Suyama K, Watanabe M, Sakabe K, Otomo A, Okada Y, Terayama $\mathrm{H}$, et al. GRP78 suppresses lipid peroxidation and promotes cellular antioxidant levels in glial cells following hydrogen peroxide exposure. PloS One. 2014 Jan; 9(1):e86951.
25. Oki AS, Bimarahmanda ME, Rahardjo MB. Increased number of fibroblasts and neovascularization after tooth extraction in Wistar rats with moderate-intensity continuous exercise. J Int Dent Med Res. 2018 Dec; 11(3):840-5.

26. Setyadewi W, Oki AS, Sunariani J. moderate intensity physical exercise effect on PMN and macrophage expression in Rattus norvegicus post tooth extraction. J Int Dent Med Res. 2017 Jan; 10(2):364-7.

\title{
Have you read the current trends in
} Medical and Health Research in the Philippines?

\section{Acta Medica Philippina} The National Health Science Journal

\author{
Access Online: www.actamedicaphilippina.org
}

